dal cells during reversible suppression of CA3c output: Evidence for pattern completion in hippocampus. Journal of Neuroscience, 9 , 3915-3928

Mizumori, S. J. Y., Perez, G. M., Alvarado, M. C., Barnes, C. A., \& McNaughton, B. L. (1990). Reversible inactivation of the medial septum differentially affects two forms of learning. Brain Research, $528,12-20$

Morris, R. G. M. (1983). An attempt to dissociate "spatial-mapping' and "working-memory" theories of hippocampal function. In W. Seifert (Ed.), Neurobiology of the hippocampus (pp. 405-432). London: Academic Press.

Nadel, L., MacDonald, L. (1980). Hippocampus: Cognitive map or working memory? Behavioral \& Neural Biology, 29, 405-409.

Olton, D. S. (1983). Memory functions and the hippocampus. In W. Seifert (Ed.), Neurobiology of the hippocampus (pp. 335-373). London: Academic Press.

OLtoN, D. S. (1990). Dementia: Animal models of the cognitive impairments following damage to the basal forebrain cholinergic system. Brain Research Bulletin, 25, 499-502.

Olton, D. S., Walker, J. A., Gage, F. H. (1978). Hippocampal connections and spatial discrimination. Brain Research, 139, 295-308.

Poucet, B. (1989). Object exploration, habituation, and response to a spatial change in rats following septal or medial frontal cortical damage. Behavioral Neuroscience, 103, 1009-1016.

RifkKinen, P., JR., Sirviö, J., RiekKanen, P. (1990). Similar memory impairments found in medial septal-vertical diagonal band of Broca and nucleus basalis lesioned rats: Are memory defects induced by nucleus basalis lesions related to the degree of non-specific subcortical cell loss? Behavioural Brain Research, 37, 83-88.

SAPER, C. B. (1984). Organization of cerebral cortical afferent systems in the rat. I. Magnocellular basal nucleus. Joumal of Comparative Neurology, 222, 313-342.

Segal, M., Greenberger, V., \& PeArl, E. (1989). Septal transplants ameliorate spatial deficits and restore cholinergic functions in rats with a damaged septo-hippocampal connection. Brain Research, 500, 139-148.

Sutherland, R. J., \& Rodriguez, A. J. (1989). The role of the fornix fimbria and some related subcortical structures in place learning and memory. Behavioural Brain Research, 32, 265-277.

Tilson, H. A., Harry, G. J., Mclamb, R. L., Peterson, N. J., Rodgers, B. C., Pediaditakis, P., A Al, S. F. (1988). Role of dentate gyrus cells in retention of a radial arm maze task and sensitivity of rats to cholinergic drugs. Behavioral Neuroscience, 102, 835-842.

Wenk, G. L., Markowsika, A. L., Olton, D. S. (1989). Basal forebrain lesions and memory: Alterations in neurotensin, not acetylcholine, may cause amnesia. Behavioral Neuroscience, 103, 765-769.

(Manuscript received July 22, 1991; revision accepted for publication November 18,1991 .)

\title{
Call for Assistance in The Compilation of a History of the Psychonomic Society
}

The Governing Board of the Psychonomic Society is pleased to announce that Robert C. Bolles has agreed to serve as the first Historian of the Society.

All members who might have information relevant to this undertaking are invited to send it directly to Dr. Bolles. Founding members and those who attended the early meetings are especially encouraged to record their reminiscences. While Dr. Bolles hopes to collect as much information as possible relevant to the history of the Society, he will concentrate first on the early history.

Dr. Bolles's address is Department of Psychology, University of Washington, Seattle, Washington 98195 (phone: 206-543-2631). 